\title{
Correlative Studies in Obese Children and Adoles- cents Concerning Body Composition and Plasma Insulin and Growth Hormone Levels
}

\author{
Adalberto Parra ${ }^{[4]}$, Robert B. Schultz, Joan E. Graystone, and Donald B. Cheek \\ Division of Growth and the Division of Pediatric Endocrinology, The Johns Hopkins University School of Medicine, \\ The Johns Hopkins Hospital, Baltimore, Maryland, USA
}

\section{Extract}

Levels of plasma insulin, growth hormone ( $\mathrm{HGH})$, glucose, and free fatty acids (FFA) were investigated in 17 obese, nondiabetic children or adolescents after administration of intravenous arginine, oral glucose, and a protein-glucose meal. These results were compared with those obtained in eight normal adolescents. Four of the obese patients had a family history of diabetes but had hormonal responses identical with those observed in obese subjects with a negative family history of diabetes. Subjects were arbitrarily separated into two groups depending on duration of obesity (Table I) (age of onset was different: infancy or early childhood for group $B, 5-8$ years for group $A$ ). Subjects in group $B$ (longstanding obesity) all had a strong family history of obesity with marked increases in body weight, body fat, and excess fat. Fasting levels of insulin were greater than normal $(P<0.001$ (Table II)). Patients in group $A$ (short duration), with lesser increments in body weight and body fat, had normal fasting levels of insulin and normal response to intravenous arginine (Fig. 4). All obese subjects had hyperinsulinemia in response to other stimuli, but patients in group $B$ achieved the highest insulin levels (Figs. 2, 3, and 4). All obese patients had significantly decreased levels of $\mathrm{HGH}$ during tests and elevated fasting levels of FFA. Patients in group B exhibited a reduced mean decrement in FFA during the oral glucose tolerance test.

Whether or not responses seen in patients in group $A$ represent an early stage of the conditions observed in patients in group $B$ cannot be determined by this study, but the biochemical changes reported in established obesity of childhood mimic those found in the adult.

\section{Speculation}

Obesity in children is associated with excess lipogenesis and hyperinsulinemia, which are interdependent and initiated through maximal nutritional intake in infancy.

Eventually muscle becomes resistant to insulin with decreased transport of glucose into the cell and decreased protein synthesis relative to DNA. The reduced levels of growth hormone in the circulation may indicate excessive uptake by muscle, which is followed, in some instances, by an associated proliferation of nuclei. 


\section{Introduction}

The problem of obesity has recently been reviewed [ 3 , $12,19,23,41]$.

In contrast with the voluminous data concerning hormonal abnormalities in the obese adult $[4,27,28$, $32,35,37]$, relatively little is known about the magnitude of such abnormalities in obese children or adolescents [11,33].

Previous investigators [2] have reported a correlation between total body weight and fasting levels of insulin in obese adults; others, however, have been unable to demonstrate a correlation between fasting levels of insulin and total body fat in obese adolescents $[11,15]$.

One problem has been the inability to assess normal or expected fatness in children and the degree of excess fatness in obese children. Mellits and Cheek [30] have constructed quadratic equations using data on body water and length (in centimeters) to predict "expected body fat" in the normal male and female from childhood to 30 years.

In a previous publication [10], children and adolescents with obesity were studied with respect to body composition. It was possible to inspect lean body mass, fat mass, and excess fat as well as changes in muscle and adipose tissue.

The present study was undertaken in an attempt to determine the levels of insulin and growth hormone in these same patients and to seck relationships of these hormones with body fat and body composition.

\section{Materials and Mcthods}

Serenteen obese individuals (five males and 12 females), 6.9-17.7 years of age, were selected as voluntary subjects for these studies. Body weights ranged from $47.6-179.2 \mathrm{~kg}$ and all weights were clearly above the 97 th percentile. Eight healthy nonobese youngsters (six males and two females, ranging from 9 to 18 years of age) served as a normal control group. None of the patients had received any therapy previously for their obesity. None of the patients had diabetes mellitus at the time of testing, although four patients $(0.19,056$, 057, and 060) had a family history of diabetes in either a maternal grandparent or maternal aunt.

Each subject under study was placed on a diet providing at least $250 \mathrm{~g}$ carbohydrate claily for at least 4 days prior to admission. Studies were performed in the Pediatric Clinical Research Unit of the Johns Iopkins Hospital over a period of 6 days.

The following tests were performed on separate days following an overnight fast. Oral glucose tolerance test: $1.75 \mathrm{~g}$ glucose $/ \mathrm{kg}$ actual body weight to a maximum of $100 \mathrm{~g}$. Glucose was given as a $50 \%$ solution in water. Thus, the heavier patients tested (group B) received a smaller dose of glucose per kilogram of body weight than did subjects in group $A$. Protein-glucose meal: $1 \mathrm{~g}$ beef protein $/ \mathrm{kg}$ body weight in the form of steak or hamburger was ingested simultancously with a dose of glucose equal to that received during the oral glucose tolerance test. Arginine tolerance test: $0.5 \mathrm{~g}$ L-arginine monohydrochloricle [45] per kilogram actual body weight to a maximum of $10 \mathrm{~g}$. The arginine was administered intravenously as a $10 \%$ aqueous solution over a period of $30 \mathrm{minn}$. Since an arbitrary maximum of $10 \mathrm{~g}$ was administered, the patients in group $B$ received a smaller dose of arginine per kilogram of body weight than did those in group $A$.

All blood specimens were collected from indwelling nonheparinized needles placed in the antecubital or dorsal hand vein. Samples were collected into heparinised glass test tubes and immediately centrifuged, and the plasma was separated and kept frozen at $-.1^{\circ}$ for later analysis. Blood specimens were obtained at -15 , $0,30,60,90,120,240$, and $300 \mathrm{~min}$ during the oral glucose tolerance test and at $-15,0^{1}, 0^{2}, 30,60,90$, 120, 180, 240, and $300 \mathrm{~min}$ during the protein-glucose meal. Time $0^{1}$ indicates the time at which the meal was begun and time 0" when the meal was completed. The time required for ingestion of the test meal varied between 15 and $20 \mathrm{~min}$ in all of the subjects. All subsequent times for sampling represent the time elapsed since completion of the meal.

During the arginine tolerance test blood was drawn at $-15,0,20,30,45,60,90$, and 120 min after the start of the infusion.

All determinations were performed on plasmat samples. Glucose was determined by a glucose oxidlase method [31] and free fatty acids (FFA) by the Dole method [13] as modified by Trout, Estes, and Friedberg [12]. Immunoreactive insulin (IRI) was assayed by the radioimmunoassay method of Yalow and Berson [1.1] with a slight modification [24]. Immunoreactive growth hormone (HGII) was assayed by a radioimmunoassay technique of Schalch and Parker [39]. All plasma specimens for glucose and FFA were assayed in triplicate and for IRI and IIGH in duplicate. All of these data are expressed in the text or figures as the mean \pm standard error of the estimate.

Deuterium space was used for determination of total body water (TW) and corrected bromide space for extracellular volume (ECV) [5]. Lcan body mass (LBMI) 
and total body fat (TBF) were determined by the use of the Pace constant (0.72) [1, 10]. Thus LBM and TBF may be determined from the following equation:

$$
\mathrm{LBM}=\frac{\mathrm{TW}}{0.72}
$$

It follows that: TBF $=$ body weight - LBM.

Expected body fat was also predicted from height according to the following equations [30]:

For 145 males, fat $(\mathrm{kg})=12.116-0.215$ (ht) +

$$
0.00114(\mathrm{ht})^{2}, \mathrm{SD}=3.84
$$

For 74 fcmales, fat $(\mathrm{kg})=27.514-0.538$ (ht) +

$$
0.00279(\mathrm{ht})^{2}, \mathrm{SD}=3.43
$$

For the obese individual it is possible to assess body fat from body water $[1,10]$ and subtract "expected fat" to obtain "excess fat." The identifying code numbers are the same as those employed in a previous communication [10] which describes in detail the body composition of these subjects.

\section{Results}

The obese subjects were divided into two groups based on duration of obesity, which was determined in all subjects either by annual weight records or family pictures. Subjects in group $A$ became obese at approximately 5-8 years of age and the duration ranged from 2 to 4.5 years at the time of study. Subjects in group $B$ became clinically obese either in infancy or very early childhood, but always prior to 5 years of age. The duration of obesity ranged from 6.5 to 15 years. This division was maintained during analysis of certain data to determine whether duration of obesity, irrespective of age of onset, influenced hormonal patterns. Table I summarizes the clinical data of the subjects studied.

All obese subjects in both groups were well over the 97th percentile for weight. No attempt was made to analyze critically the differences in heights of the groups because of the considerable differences in age at the time of study. There was a striking preponderance of obese family members among those in group $B$ in

\begin{tabular}{|c|c|c|c|c|c|c|c|c|c|c|}
\hline & & & & & ght & & & & Age onset & \\
\hline & Code no. & 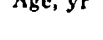 & Sex & $\mathrm{cm}$ & percentile & $\mathrm{kg}$ & percentile & Family nistory or obesity" & or obesty, & obesity, yr \\
\hline Normal group & N-61 & 15.2 & $\mathbf{M}$ & 181.4 & 97 & 78.6 & 97 & $\mathrm{~S}$ & & \\
\hline & $\mathrm{N}-62$ & 15.8 & $\mathrm{M}$ & 187.0 & $>97$ & 76.5 & 97 & Negative & & \\
\hline & N-63 & 17.5 & $\mathbf{M}$ & 171.9 & 25 & 59.3 & 25 & Negative & & \\
\hline & G.3 & 11.0 & $\mathrm{M}$ & 148.7 & 75 & 41.5 & 75 & B & & \\
\hline & $G-6$ & 14.3 & $\mathrm{M}$ & 165.0 & 50 & 52.1 & 50 & s & & \\
\hline & $\mathrm{PR}$ & 8.9 & $\mathrm{M}$ & 148.7 & $>97$ & 37.7 & 90 & Negative & & \\
\hline & $N-1 ; 0$ & 18.0 & $F$ & 160.0 & 25 & 51.1 & 25 & $S$ & & \\
\hline & $\mathrm{JR}$ & 12.3 & $\mathrm{~F}$ & 168.1 & $>97$ & 48.6 & 75 & Negative & & \\
\hline Obese group $A$ & 053 & 9.3 & $\mathbf{M}$ & 141.0 & 75 & 55.0 & $>97$ & $\mathrm{~F}, \mathrm{M}, \mathrm{B}$ & $6-7$ & 3 \\
\hline & 041 & 10.0 & $\mathrm{~F}$ & 152.0 & 97 & 62.7 & $>97$ & Negative & $7-8$ & 3 \\
\hline & 050 & 6.9 & $\mathrm{~F}$ & 129.5 & 90 & 47.5 & $>97$ & Negative & $5-6$ & 2 \\
\hline & 055 & 11.8 & $\mathrm{~F}$ & 150.5 & 50 & 63.2 & $>99$ & Negative & $7-8$ & 4.5 \\
\hline & 062 & 11.0 & $\mathrm{~F}$ & 145.0 & 50 & 60.3 & $>97$ & Negative & $8-9$ & 3 \\
\hline Obese group $B$ & 047 & 16.7 & $\mathbf{M}$ & 185.4 & 97 & 196.3 & $>97$ & F, B & $2-3$ & 14.5 \\
\hline & 051 & 14.2 & $\mathrm{M}$ & 172.7 & 90 & 109.1 & $>97$ & $\mathrm{~F}, \mathrm{~B}$ & $3-4$ & 11 \\
\hline & 054 & 14.2 & $M$ & 171.5 & 90 & 96.4 & $>97$ & $F, M, B$ & $3-4$ & 11 \\
\hline & 063 & 17.7 & $\mathbf{M}$ & 182.2 & 90 & 160.0 & $>97$ & $\mathrm{GF}, \mathrm{GM}, \Lambda, \mathrm{U}$ & $3-4$ & 14.5 \\
\hline & 049 & 13.1 & $\mathrm{~F}$ & 164.0 & 90 & 76.4 & $>97$ & $\mathrm{GF}, \mathrm{GM}$ & $4-5$ & 9 \\
\hline & 052 & 10.7 & $\mathrm{~F}$ & 148.6 & 75 & 66.0 & $>97$ & $\mathrm{~F}$ & $4-5$ & 6.5 \\
\hline & 056 & 9.5 & $\mathrm{~F}$ & 137.8 & 75 & 64.9 & $>97$ & $\mathrm{M}, \mathrm{GF}, \mathrm{GM}, \mathrm{A}$ & $2-3$ & 7.5 \\
\hline & 057 & 17.0 & $\mathrm{~F}$ & 154.9 & 10 & 109.2 & $>97$ & $\mathrm{M}, \mathrm{GF}, \mathrm{GM}, \mathrm{A}$ & $2-3$ & 15 \\
\hline & 058 & 9.2 & $\mathrm{~F}$ & 154.8 & $>97$ & 62.7 & $>97$ & $\mathrm{M}$ & $1-2$ & 8 \\
\hline & 059 & 12.1 & $\mathrm{~F}$ & 154.0 & 75 & 77.9 & $>97$ & $\mathrm{GF}, \mathrm{GM}, \Lambda, \mathrm{U}$ & $2-3$ & 10 \\
\hline & 060 & 13.5 & $\mathrm{~F}$ & 165.0 & 90 & 127.5 & $>97$ & $\mathrm{~F}, \mathrm{M}$ & $3-4$ & 10 \\
\hline & $0(; 1$ & 14.1 & $\mathrm{~F}$ & 160.0 & 50 & 98.4 & $>97$ & GF, GM, A & $2-3$ & 12 \\
\hline
\end{tabular}
contrast to those in group $A$.

Table $I$. Clinical data

I F : Father. M:Mother. B: Brother. S: Sister. GF: Grandfather. GM: Grandmother. $\perp$, U : Aunt or Uncle. 
Table II. Biochemical datia

\begin{tabular}{|c|c|c|c|c|c|c|c|c|c|c|}
\hline & $\begin{array}{l}\text { Code } \\
\text { no. }\end{array}$ & $\begin{array}{l}\text { Fcl: } \\
\text { liters }\end{array}$ & $\underset{\mu U / m l}{\text { Fasting }} \mid k I$, & $\begin{array}{c}\text { Protein- } \\
\text { glucose meal } \\
\text { peik IKI, } \mathrm{UU} / \mathrm{ml}\end{array}$ & Weight, kg & THFing & THF, ci, looly & $\underset{\mathrm{kg}}{\text { Excess fat, }}$ & $\begin{array}{l}\text { lixcess fat, } \\
\text { \% boily wit }\end{array}$ & $\underset{\mathrm{kg}}{\mathrm{LHMI}}$ \\
\hline \multirow{8}{*}{ Normal group } & $N-(i)$ & 17.37 & 20.4 & 174.0 & 78.6 & 18.5 & & 0.0 & & 60.1 \\
\hline & N-ti2 & 18.49 & 22.0 & 211.0 & 76.5 & $1: 3.0$ & & 0.0 & & 63.5 \\
\hline & $N-(i ; 3$ & 14.10 & 24.7 & 280.0 & 59.3 & 7.9 & & 0.0 & & 51.4 \\
\hline & G -3 & 9.43 & 17.8 & $1: 3+.0$ & 41.5 & 5.5 & & 0.0 & & 36.0 \\
\hline & G-ti & 11.92 & 20.1 & 52.0 & 52.1 & N..l.4 & & N.A. & & N... \\
\hline & PR & N... & 23.6 & 76.0 & 37.7 & N..l. & & N... & & N.I. \\
\hline & $N-(x)$ & 10.87 & 15.2 & $2(x) .0$ & 51.1 & 12.0 & & 0.0 & & 39.1 \\
\hline & $J k$ & N.... & 21.0 & 105.0 & 48.6 & N..I. & & N.A. & & N.A. \\
\hline \multirow[t]{5}{*}{ Obese group A } & 0.53 & 11.0 .1 & 14.0 & 217.0 & 55.0 & 19.7 & $3 i$ & 15.2 & 27.5 & 35.3 \\
\hline & 0.11 & 10.81 & 4.7 & $2: 34.0$ & 62.7 & 28.7 & 46 & 18.4 & 29.0 & 34.0 \\
\hline & 050 & 3.14 & 19.8 & $17: 3.0$ & 47.5 & 14.5 & 30.5 & 9.8 & 21.0 & 33.0 \\
\hline & 05.5 & & 25.1 & 224.0 & 63.2 & 29.3 & 46 & 19.6 & 31.0 & 33.9 \\
\hline & (1)i2 & 11.41 & 20.7 & $266 j .0$ & 60.3 & 22.3 & 37 & 10.7 & 18.0 & 38.0 \\
\hline \multirow[t]{12}{*}{ Obese group $B$} & 0.47 & 35.12 & 44.1 & 520.0 & $19 K .3$ & 100.7 & 51 & 89.2 & 45.0 & 95.6 \\
\hline & 0.51 & N.A. & 49.8 & 1120.0 & $1(x) .1$ & N.A. & & N... & & N.A. \\
\hline & 0.54 & 13.19 & 40.5 & 824.0 & 16.4 & 36.9 & 38 & 28.1 & 29.0 & 59.5 \\
\hline & 06.3 & 28.12 & 38.5 & 328.0 & 160.0 & 93.4 & 58 & 82.6 & 52.0 & 66.6 \\
\hline & (2H!) & 17.2 .4 & $\$ 4.0$ & 384.0 & 76.4 & 34.5 & 45 & 20.1 & 26.0 & 41.9 \\
\hline & 0.52 & 11.60 & 35.5 & 510.0 & 66.0 & 25.3 & 38 & 16.1 & 24.0 & 40.7 \\
\hline & $0 \%$ & 11.13 & 46.5 & 872.0 & 64.9 & 24.1 & 37 & 17.7 & 27.0 & 40.8 \\
\hline & 0.57 & 17.2 .4 & 45.0 & $f(x) .0$ & 10.9 .2 & 56.6 & .52 & 45.5 & 42.0 & $.52 .6 \mathrm{j}$ \\
\hline & 0.58 & 11.10 & 30.1 & 276.0 & 72.7 & 20.0 & 32 & 9.0 & 14.5 & 42.7 \\
\hline & 0.59 & 11.12 & 39.8 & 6800.0 & 77.9 & 36.3 & 41.5 & 25.5 & 33.0 & 41.6 \\
\hline & 060 & 20.63 & 53.5 & N.A. & 127.5 & 50.3 & 34.5 & 35.6 & 28.0 & 77.2 \\
\hline & 061 & 15.28 & 32.4 & 3.4 .4 .0 & 98.4 & 40.9 & 41.5 & 28.0 & 28.5 & 57.6 \\
\hline
\end{tabular}

I IRI : Imumoreactive insulin. TBF : Total body fat. LBM : L, can body mass.

'TBF : Body weight - LBM.

3 Lexess fat $=$ actual body fat - predicted boxly fat [30].

'N.L.: Ditla not available.

\section{Body Fat and Excess Fat}

Datat on body weight, body fitt, and excess fat are recorded in Table II. The older the patient, the heavier the patient and the greater the body fat. Accordingly, excess fatness increased with time. Body weight, body fat, and excess fat are, of course, greatly in excess for age or body length by comparison with normal children; however, body fat expressed as a percentage of bodly weight yields values for group $A$ of $30-16$ and for group $B$ of 32-58. An overlap exists.

\section{Fasting I'Aasma IRI Levels and Circulaling Insulin}

The levels for IRI are presented in Table II. The fasting levels of IRI in each subject represent the mean value of six simples obtained after six consecutive overnight fasts.

The fasting level of insulin in the normal group was $20.6 \pm 2.7 \mu \mathrm{U} / \mathrm{ml}$ and $16.9 \pm 3.4$ and $11.6 \pm 1.9$ $\mu \mathrm{U} / \mathrm{ml}$ in obese groups $A$ and $B$, respectively. The difference between normal subjects and those in group $A$ was not significant. The values were significintly different, however, between those in obese group $B$ and the normal group $(P<0.001)$ and between both obese groups $(P<0.001)$.

An increasing ratio of fat to body weight did not correlate with the fasting insulin level; nevertheless, the extra fat in terms of absolute amounts appeared to hold some relation with the levels of fasting insulin. If a rough measure of the circulating insulin is obtained by multiplying plasma concentration of insulin by $\mathrm{cx}$. tracellular volume [14] then the corrclation of this detcrminant against "cxcess fat" is found to be high $(r$ $=0.92)$. Moreover, if circulating insulin is considered in relation to total body fit or excess fat as a percent. age of body weight, the correlation is still reasonable $(r$ $=0.70)$. Thus the degree of fatness or excess fat would appeat (o be associated with the amount of circulating insulin. Although the fasting concentration of insulin was higher in patients of group $B$ but did not corre- 
late with fat as a percentage of body weight, it appeared that the longer the duration of obesity, the higher the level of fasting insulin (Fig. 1).

\section{Plasma Insulin and the Response to Glucose and Pro- tein}

The values for IRI during the oral glucose tolerance test are shown in Figure 2. Obese group $A$ had levels of IRI significantly higher than those found in the normal group at 30 and $180 \mathrm{~min}(P<0.005$ and $<0.05)$ Obese group $B$ achieved levels of IRI greater than those seen in the normal group at $30,90,120$, and 180 $\min (P<0.02,<0.05,<0.05$, and $<0.005)$. All three groups had their peak IRI responses at $30 \mathrm{~min}$.

The responses to the protein-glucose meal are presented in Figure 3. Obese group $A$ showed significantly higher levels of IRI than did those in the normal group at only time $0^{2}(P<0.02)$. The values for IRI were significantly different, however, between obese group $B$ and the normal group throughout the entire test $(P$ range between $<0.02$ and $<0.001$ ), and between both obese groups at $30,60,90,120,180$, and $300 \mathrm{~min}(P$ range between $<0.05$ and $<0.005)$. The peak responses of IRI were achieved at $30 \mathrm{~min}$ in all three groups.

During the arginine tolerance test obese group $A$ had levels of IRI not significantly different from normal subjects (Fig. 4). Obese group B, however, had values for IRI significantly higher than that found in the normal group at $15,30,45,60$, and $90 \mathrm{~min}(P$ $<0.005,<0.005,<0.005,<0.05$, and $<0.01)$ and higher than that found in obese group $A$ at 30,45 , and

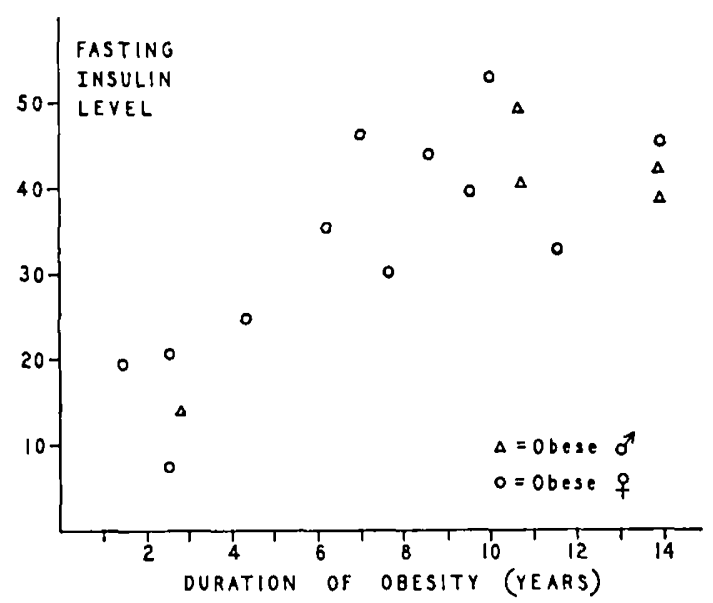

Fig. 1. Relationship between duration of obesity (years) and fasting plasma immunoreactive insulin levels as conventionally expressed in microunits per milliliter. The points appear to rise progressively.
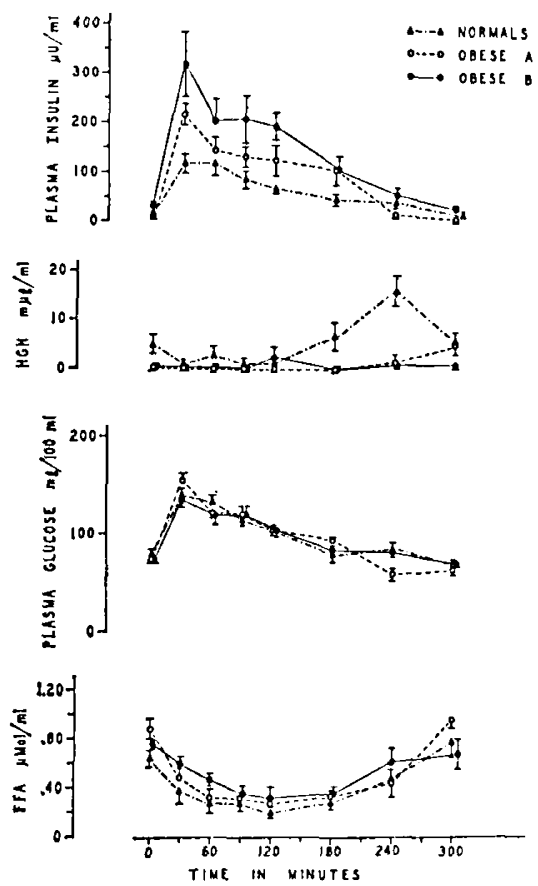

Fig. 2. Oral glucose tolerance test. Plasma levels of insulin, growth hormone (HGH), glucose, and free fatty acids (FFA) in the groups studied. The values represent mean \pm SEN.

$90 \min (P<0.05<0.02$, and $<0.05)$. Once again, the three groups reached peak values of IRI at $30 \mathrm{~min}$.

\section{Plasma Growth Hormone (HGH) Levels}

The mean fasting value in the normal groups was $3.6 \pm 0.9 \mathrm{~m} \mu \mathrm{g} / \mathrm{ml}$, compared with $0.5 \pm 0.2$ and $0.3 \pm$ $0.1 \mathrm{~m} \mu \mathrm{g} / \mathrm{ml}$ in obese groups $A$ and $B$, respectively. The differences were significant between normal subjects and those in group $A(P<0.005)$ and between normal subjects and those in group $B(P<0.001)$ but not between both obese groups.

The values for $\mathrm{HGH}$ in the normal group during the oral glucose tolerance test were significantly higher than those seen in obese group $A$ at 180 and $240 \mathrm{~min}$ $(P<0.05$ and $<0.05)$ and higher than that observed in obese group $B$ at 240 and $300 \mathrm{~min}(P<0.02$ and $<0.05)$. The level of $\mathrm{HGH}$ at $300 \mathrm{~min}$ was significantly grcater in obese group $A$ than that in $B(P<0.05)$ (Fig. 2). The mean peak response of HGH was $15.2 \pm$ $2.6 \mathrm{~m} \mu \mathrm{g} / \mathrm{ml}$ in the normal group compared with $5.7 \pm$ $1.5 \mathrm{~m} \mu \mathrm{g} / \mathrm{ml}$ in obese group $A(P<0.01)$ and $3.9 \pm 1.6$ $\mathrm{m} \mu \mathrm{g} / \mathrm{ml}$ in obese group $B(P<0.005)$. The differences between both obese groups were not significant.

In response to arginine stimulation (Fig. 4) the normal group had values for HGH that were significantly higher than those seen in obese group $A$ or $B$ at 60 and 

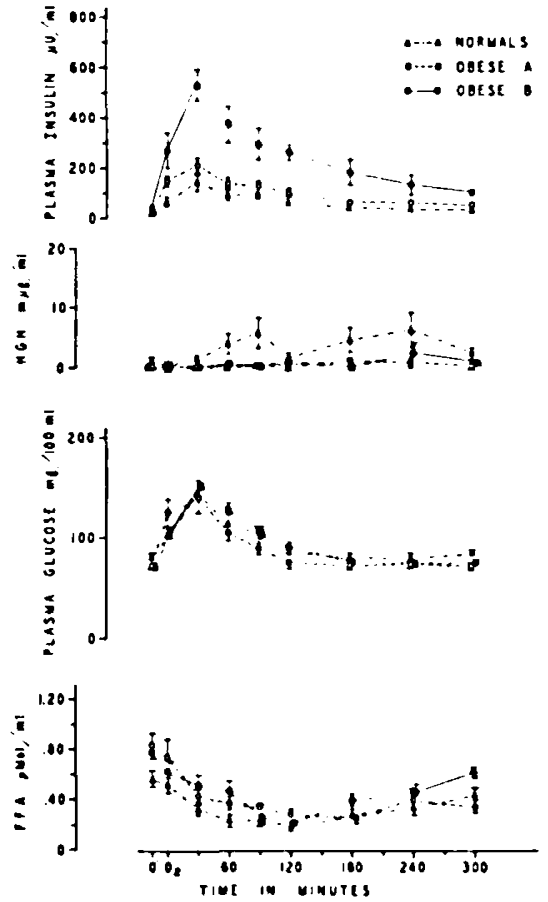

Fig. 3. Protcin-glucose meal. Plasma levels of insulin, growth hormone (HGI), glucose, ant fre fatty acids (FFA) in the groups studied. The values represent me:un \pm ssas. The significant differences referred to in the text are valid although the figure does not appear to reflect these differences accurately.
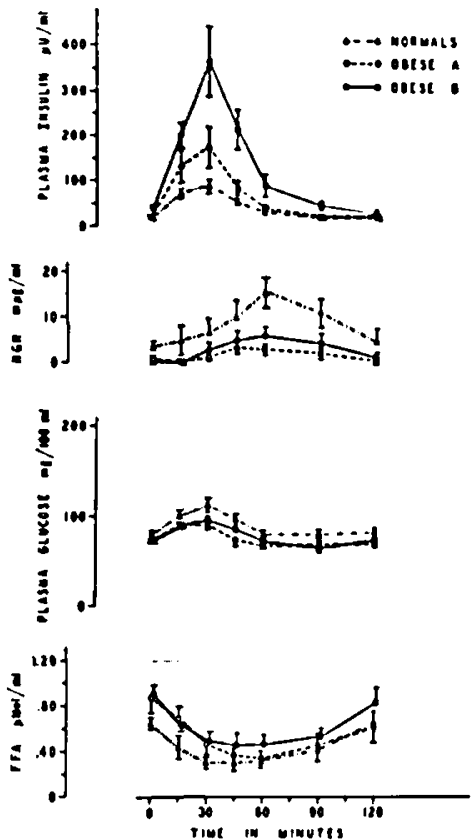

Fig. f. Arginine tolerance test. Plavilla levels of insulin, growth hormone (IIGII), glucose, and free fatty acids (FFA) in the groups studied. The balues represent mean \pm sho. The significant differences iefened to in the text are valid although the figure does not appear to reflect these differences accuratcly.
$90 \mathrm{~min}(P<0.05$ and $<0.05)$. The mean peak response for HGH was $15.4 \pm 3.7 \mathrm{~m} \mu \mathrm{g} / \mathrm{ml}$ in the normal group, $1.1 \pm 1.3 \mathrm{~m} \mu \mathrm{g} / \mathrm{ml} \mathrm{in}$ olsese group $A\left(l^{\prime}<0.025\right)$, and $\left(i .5 \pm 2.2 \mathrm{~m} \mu \mathrm{g} / \mathrm{ml}\right.$ in obese group $B\left(l^{\prime}<0.05\right)$. The differences between both obese groups were not significant.

\section{Plasma Glucose}

The fasting level of glucose in the normal group was $80.5 \pm 1.9 \mathrm{mg} / 100 \mathrm{ml}$, and $74.0 \pm 0.9 \mathrm{mg} / 100 \mathrm{ml}$ for obese group $A(P<0.005)$ and $72.9 \pm 0.8 \mathrm{mg} / 100 \mathrm{ml}$ for obese group $B\left(I^{\prime}<0.001\right)$. These differences were significant between normill subjects and group $A(P<$ $0.005)$ and normal subjects and group $B\left(l^{\prime}<0.001\right)$ but not between obese groups.

During the glucose colerance test all of the glucose values were within normal limits (Fig. 2). The only significantly different value between normal subjects and obese group $A$ was at $2.10 \mathrm{~min}(P<0.05)$. There were no differences between normal subjects and obese group $B$ or between both obese groups.

During the protein-glucose meal (Fig. 3) the normal group had values for glucose significantly higher than obese group $A$ at 180 and $300 \mathrm{~min}(P<0.05$ and 0.01$)$ and than obese group $B$ at $300 \mathrm{~min}(P<0.025)$. However, no significant differences were observed between both obese groups.

During arginine stimulation (Fig. 4) the levels of glucose in the normal group were significantly greater than in obese group $A$ at 30 , f(0, and $90 \mathrm{~min}(P<0.05$, $<0.05$, and $<0.05)$ and than in obese group $B$ only at 90 min $(P<0.05)$. The values in both obese groups were not significantly dillerent.

\section{Plasma Frec Fatly Acids (FFA)}

The normal mean fasting level of FFA was $0.621 \pm$ (1.010 $\mu \mathrm{mole} / \mathrm{ml}$ as compitred with $0.873 \pm 0.056 \mathrm{scen}$ in obese group $A(P<0.001)$ and $0.835 \pm 0.030$ almole $/ \mathrm{ml}$ in obese group $B\left(I^{P}<0.001\right)$. There was no significant difference between both obese groups.

During the oral glucose and arginine tests no significant differences in the albsolute values in FFA were observed between each of the groups (Figs. 2 and 4). During the protein-glucose meal, however (Fig. 3), obese group $B$ had significantly higher values for $\mathrm{FF} A$ than the normal group at 60 and $300 \mathrm{~min}(P<0.025$ and $<0.01)$ and than the obese group $A$ at $300 \mathrm{~min}(P$ $<0.005)$.

When the values for Fisd were expressed as mean decrenents from the basal level, during the oral glucose tolerance test, there were no significant differences 
between the normal group and obese group $A$. At 30 min, however, the normal group achieved a significantly greater decrement than did obese group $B(P<$ 0.05 ). Obese group $A$ also had a significantly greater decrement than obese group $B$ at 30 and 60 min $(P<$ 0.01 and $<0.01$ ). No significant differences were observed during either the protein-glucose meal or the arginine tolerance test.

\section{Muscle Protein/DNA and Peak IRI Levels}

In previous work [10] the finding of a reduced protein/DNA ratio was made in the muscle of these obese subjects. Figure 5 depicts the relation between these values and the peak insulin response induced by the glucose-protein meal. In the figure the expected protein/DNA ratio (call size or cytoplasmic index) and the expected peak insulin level for normal children are shown. The figure illustrates the probability that high levels of insulin are required to achieve protein accretion relative to DNA within the muscle.

\section{Discussion}

Overweight children were divided initially into two groups depending on duration of obesity. The age of onset differed in that patients in group $A$ became obese at 5-8 years of age and the duration ranged from 2 to 4.5 years at the time of study, whereas patients in group $B$ were obese from infancy or early childhood and the duration ranged from 6.5 to 15 years. A priori, one could consider that the two groups represent different populations. There was an overlap in excess fatness expressed as a percentage of body weight, however, so that the two groups may differ only in age of onset and duration of obesity. Excess fatness must, under these circumstances, increase with age and duration of obesity, and the differences in hormonal response would correlate with either of the situations.

The fasting levels of insulin were abnormally high in patients of group $B$; on stimulation, HGH levels were lower and levels of FFA and insulin were higher. The fact that absolute values for excess fat correlated with circulating amounts of insulin could mean that with increasing "excess fatness" for age or body length the stimulation to the pancreas for insulin release is augmented. If such is the case then the patients under study may represent a single group at different stages.

Paulsen, Richenderfer, and Ginsberg-Fellner [33] demonstrated hyperinsulinemia in obese children and found that those patients with abnormal glucose tolerance had the highest insulin levels. Patients with a family history of diabetes had, on stimulation with

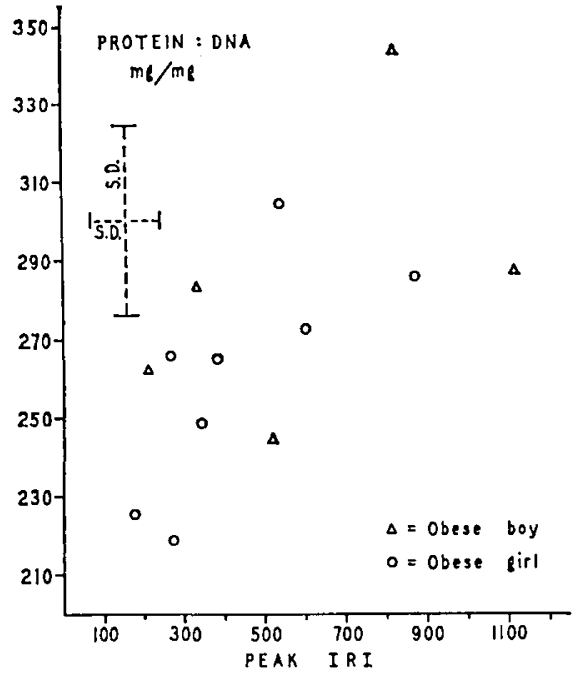

Fig. 5. The muscle cell size (protein/DNA) for obese boys and girls (see reference 10 for data) is plotted against the peak insulin response produced by a protein-glucose meal. On the left side of the figure is shown the cell size for normal children with the standard deviation (300 $\pm 27 \mathrm{mg}$ protein $/ \mathrm{mg}$ DNA) and also the cxpected peak insulin response $(161 \pm 84 \mu \mathrm{U} / \mathrm{ml}$ plasma).

glucose, higher insulin levels than those without such a history. Chiumello et al. [11] found no differences in insulin levels in obese children with or without a family history of diabetes. They found that once body weight exceeded ideal weight by $35 \%$ then hyperinsulinemia existed.

In recent years it has become apparent that in obesity certain tissues become resistant to insulin $[20,29$, $36,40]$. Subjects in the present study produced greater than normal amounts of insulin to maintain normal glucose tolerance. In vitro studies [20] have demonstrated the relative insulin resistance of intact adipose tissue compared with isolated fat cells in translocating glucose. The question of diffusion of insulin within the connective tissue framework may be important.

With respect to muscle, Stauffacher et al. [40] showed that incorporation of ${ }^{14} \mathrm{C}$-glucose is significantly reduced in the diaphragm of obese mice. Felig, Marliss, and Cahill [16] have interpreted the rise in levels of valine, leucine, isoleucine, tyrosine, and phenylalanine in the blood of obese patients in the postabsorptive state as indicating tissue resistance to insulin since there is good evidence that increases in plasma insulin inhibits the release of amino acids from muscle [34].

Our own work has shown that the protein/DNA ratio in muscle is reduced in obesity when the base line is organ size or muscle mass. Although some patients have an increase in muscle mass (and muscle. 
protein content) the increment in the DNA content is even greater. Elsewhere [8] the theory has becn postulated that muscle increments in protein relative to 1)N $\lambda$ reflect the balance between HGH and insulin. If insulin is less effective, then the action of HGH predominates; hence an increase in nuclei number within the musculature is to be expected [10]. Possibly the low circulating levels of HGH scen in this study indicate an excessive uptake by muscle while the reduction of protein relative to $\mathrm{DNA}$ indicates the ineffectiveness of insulin. In a sense, then, the reduction of protein/ DNA resembles protein deprivation [9] and it is of interest that valine, leucine, and isoleucine also are increased in the circulation in starvation [17].

The prediction that IIGH predominates also wats suggested by the recent report of Hansen [22] which showed that in uncontrolled juvenile diabetes the im. position of exercise causes a large increase in HGH production. His patients, however, were not obese.

Grodsky [21] studied obese patients after weight reduction and found that pancreatic stimulation no longer produced excessively high insulin levels while boshell et al. [4] did not consider this finding consistent. The weight of evidence would suggest that insulin secretion and excess fatness increase commensurately during the progress of obesity in the human and in the experimental animal [29].

Oremutrition in infancy which has been shown to produce overgrowth [18] maty play an extremely important role in determining changes in number and size of cells in different tissues $[26,43]$. Such changes may be irreversible if they persist into adolescence or early life $[6,25]$.

\section{Summary}

Stuclies of levels of plasma insulin, growth hormone (HGII), free fatty acids (FF $\Lambda$ ), and glucose were performed on 17 obese, nondiabetic children. Children with longstanding obesity had fasting hyperinsulinemia and following stimulation had elevated concentrations of FFA and insulin. All obese subjects had depression of IIGH levels. The subjects were divided into two groups depending on duration of obesity. Patients with obesity of short duration (who developed obesity late or at 5-9 years of age) had normal fasting levels of insulin and normal insulin responses to intravenous arginine administration.

Information is presented which suggests a role for insulin in the perpetuation of the obese state and attention is drawn to hyperinsulinemia coincidental with reduced protein/DN $\Lambda$ in muscle. The amount of excess fat corrclated closely with a rough estimate of circulating insulin (concentration times volume of distribution).

\section{References and Notes}

1. Babinenu, L. M., AND PAGE, E.: On body fat and borly water in rats. Can. J. Biocheın. Physiol., 33: 970 (1955).

2. Bacdade, J. D., Bitrman, E. L., ANd Porte, D., JR.: The significance of basal insulin response to glucose in diabetic and non-diabetic subjects. J. Clin. Invest., 46: 15.49 (1967).

3. Borjeson, J.: Overweight children. Acta Pacdiat. Scand., 51: suppl. 123, 7 (1962).

4. Bosilele, B. R., Gihndalia, II. B., Kreisierg, R. A., AND RodDARN, R. F.: Serum insulin in obesity and diabetes mellitus. Amer. J. Clin. Nutr., 21 : 1419 (1968).

5. CuefK, D. B. (Editor): Iluman Growth (Lea and Febiger, Philadelphia, 1968).

6. CheEK, D. B.: Cellular growth, hormones, nutrition and time. Pediatrics, $11: 30$ (1968).

7. Chefk, D. B., and Graystone, J. E.: The action of insulin, growth hormone and epineplirine on cell growth in liver, muscle and brain of the hypophysectomized rat. Pediat. Res., 3: 77 (1969).

8. CiteEK, D. B., AND IIIt.L, D. E.: Muscle and liver cell growth: role of hormones and nutritional factors. Fed. Proc., 2\%: $1: 503(1970)$.

9. Cheek, D. B., Hill, D. F., Cordano, A., ANd Graina, G.: Malnutrition in infancy: changes in muscle and adipose tissue before and after rehabilitation. Pediat. Res., 4: 135 (1970).

10. Cheek, D. B., Schultz, R. B., Parra, A., and Reba, R. C.: Body composition and muscle cell growth in obcsity-the overgrowth of lean and adipose tissues in adolescent obcsity. l'cliat. Res., 4: 269 (1970).

11. Chiumello, G., Del Guercio, M. J., Carnelutti, M., and BıDone, G.: Relationship between obesity, chemical diabetes and beta pancreatic function in children. Diabetes, 18: 238 (1969).

12. Citristian, J. E., Combs, L. W., and Kessler, W. V.: The body composition of obesc subjects. Amer. J. Clin. Nutr., 15: 20 (1964).

13 DOLE, V. P., ANd MeinerTz, H.: Microdetermination of long chain fatty acids in plasma and tissues. J. Biol. Chem., 235: 2595 (1960).

14. Elgee, N. J., Williams, R. H., ANd LeE, N. D.: Distribution and degradation studies with insulin $1^{151}$. J. Clin. Invest., 33: 1252 (1954).

15. El-Khodary, A. Z., Ball, M. F., and Canary, J. J.: Plasma insulin levels and body composition in obesity. Clin. Res., 16: 341 (1968).

16. Felig, P., Marliss, E., and Cainll, G. F.: Plasma amino acid levels and insulin secretion in obesity. New Engl. J. Mfed., 2S1: 811 (1969).

17. Felig, P., Owen, O. E., Whaten, J., and Cahill, G. F.: Amino acid metabolism during prolonged starvation. J. Clin. Invest., 48: 584, (1969).

18. Fomon, S. J., Filer, L. J., THomas, L. N., Rogrrs, R. R., AND P'roksci, A. M.: Relationship between formula concentra- 
tion and rate of growth of normal infants. J. Nutr., 98: 241, (1969).

19. leorbes, G. 13.: Lean body mass and fat in obese children. Pediatrics, 34: 308 (1964).

20. Glieman, J.: Action of insulin on isolated fat cells. Danish Mfed. Bull., 16: suppl. IV, 15 (1969).

21. Grodsky, G.: Metabolic considerations in obesity. In: N. Wilson: Obesity, p. 67 (Davis, Philadelphia, 1969).

22. IIANSEN, A. P.: Abnormal serum growth hormone response to exercise in juvenile diabetes. J. Clin. Invest., 49: 1467 (1970).

23. Heald, F. P.: Natural history and physiological basis of adolescent obesity. Fed. Proc., 25: 1 (1966).

24. Herbert, V., LaU, K. S., Gottlieb, C. W., and Bleicher, S. J.: Coated charcoal immunoassay of insulin. J. Clin. Endocrinol. Metab., 25: 1375 (1965).

25. Hirsci, J., Knittle, J. L., and Salans, L. B.: Cell lipid content and cell number in obese and nonobese human adipose tissue. J. Clin. Invest., 45: 1023 (1966).

26. KNittle, J., AND HiRsci, J.: Infantile nutrition as a determinant of adult adipose tissue metabolism and cellularity. Clin. Res., 15: 323 (1967).

27. Kreishferg, R. G., Boshell, B. R., DiPlacido, J., ANd Roddarn, R. F.: Insulin secretion in obesity. New Engl. J. Med., 276: 314 (1967).

28. Lessof, M. HI, AND Greenwood, F. C.: Growth hormone secretion in obese subjects. Guy's IIosp. Rep., 115: 65 (1966).

29. Malaisse, W. J., Malaisse-Lague, D. L., and Coleman, D. L.: Insulin secretion in experimental obesity. Metabolism, 17: 802 (1968).

30. Mellits, E. D., AND Gheek, D. B.: The assessment of body water and fatness from infancy to adulthood. Monogr. Soc. Res. Child Develop. (in press).

31. McCann, W. P., AND JUdE, J. R.: The synthesis of glucose by the kidney. Bull. Johns I Iopkins Hosp., 103: 77 (1958).

32. Perley, M., And Kipnis, D. M.: Plasma insulin responses to glucose and tolbutamide of normal wcight and obese diabetic and non-diabetic subjects. Diabetes, 15: 867 (1966).

33. Paulsen, E. L., Richenderfer, F., and Ginsberg-Fellner, F.: Plasma glucose, fice fatty acids and immunoreactive insulin in sixty-six obese children. Diabetes, 17: 261 (1968).

34. Pozefsky, T., Felig, P., Tobin, J. D., Soeldner, J. S., AND CAHILL, G. F.: Anino acid balance across tissues of the fore- arm in post-absorptive man. Effect of insulin at two dose levels. J. Clin. Invest., 4S: 2273 (1969).

35. Raminowitz, D., Merimef, T. J., Niltson, J. K., Scilultz, R. B., AND Riggs, L.: The hormonal profile in obesity. Trans. Ass. Amer. Physicians Philadelphia, 80: 190 (1967).

36. RABINowitz, D., AND ZIELER, K. L.: Forearm metabolisms in obesity and its response to intra-arterial insulin. Characterization of insulin resistance and evidence for adaptative hyperinsulinism. J. Clin. Invest., 41: 2173 (1962).

37. Salans, L. B., Knitrle, J. L., ANd Hirscil, J.: The role of adipose cell size and adipose tissue insulin sensitivity in the carbohydrate intolcrance in human obesity. J. Clin. Invest., 47: 153 (1968).

38. SAlter, J., AND Best, C. H.: Insulin as a growth hormone. Brit. Med. J., 2: 354 (1953).

39. Schatci, D. A., AND PARKER, M. L.: $\Lambda$ sensitive double antibody immunoassay for human growth hormone in plasma. Nature, 203: 1141 (1964).

40. Stauffacher, W., Crofford, D. B., Jeanrenaud, B., ANd RENold, A. B.: Comparitive studies of muscle and adipose tissue metabolism in lean and obese mice. Ann. N. Y. Acad. Sci., 131: 534 (1965).

41. Stunkard, A. J.: Environment and obesity: recent advances in our understanding of regulation of food intake in man. Fed. Proc., 27: 1367 (1968).

42. Trout, D. L., Estes, E. II., JR., ANd Frifdberg, S. J.: Titration of free fatty acids of plasma: $\Lambda$ study of current methods and a new modification. J. Lipid Res., 1: 199 (1960).

43. WINICK, M. AND Noble, A.: Cellular response with increased fecding in neonatal rats. J. Nutr., $91: 179$ (1967).

44. Yalow, R. S., AND Berson, S. A.: Immunoassay of endogenous plasma insulin in man. J. Clin. Invest., 39: 1157 (1960).

45. Cutter Laboratories.

46. Supported by Public Health Service Rescarch Grant no. 1ID00126-07.

47. Dr. PARrA was supported by International Postdoctoral Research Fellowship no. 1 F05 TW 1400-01 from the National Institutes of Health.

48. Requests for reprints should be addressed to: Donald B. Cheek, M.D., Johns Hopkins Hospital, 601 North Broadway, Baltimore, Mrd. 21205 (USA).

49. Accepted for publication December 8, 1970. 